\title{
PRINCIPLES OF AUTOMATED DATA PROCESSING OF MANDELSTAM - BRILLOUIN BACKSCATTER CHARACTERISTICS FOR EVALUATING THE STATE OF OPTICAL FIBERS
}

DOI: $10.36724 / 2072-8735-2020-14-8-47-52$

Manuscript received 28 April 2020;

Accepted 05 August 2020

Igor V. Bogachkov,

Omsk State Technical University (OmSTU), Omsk, Russia, bogachkov@mail.ru

Keywords: single-mode optical fiber, Mandelstam Brillouin scattering, reflected signal, Brillouin frequency shift, profile of the backscatter spectrum

For early diagnostics of the state of optical fibers (OFs) located in the laid optical cables (OCs), it is necessary to identify potentially unreliable sections of the $\mathbf{S}$ in advance, which over time can lead to the destruction of fibers and disrupt the normal operation of fiberoptic communication lines (FOCLs). For diagnosis and forecasting of the state of the OFs that are in the laid OCs, Brillouin optical pulse reflectometers (BOTDR) are used, in which the back-reflected signal of the spontaneous Mandelstam - Brillouin scattering (MBS) is analyzed. In the process of obtaining a trace of the distribution of the Mandelshtam - Brillouin backscatter spectrum (MBBS) along the OF, the Brillouin frequency shift (BFS) is determined. After this, a graphs of the distribution of strain along the light-guide is constructed. A classification of varieties of singlemode optical fibers based on analysis of the MBS characteristics is discussed in this paper. It is shown how by the characteristics of the frequency profiles of the MBBS, one can determine the type of fiber and also evaluate the change in the strain and BFS. The MBBS profile come under influence by the functional dependence of the distribution of acoustic modes in the OF, their longitudinal direction. Both of them depend on the structure of the OF layers, as well as on the types and concentration of various alloying additives of the core OF. For single-mode OFs, when describing the MBS process, it is necessary to take into account the spatial distribution and interaction of the main optical and several acoustic modes. After uploading the data file from the BOTDR, it is necessary to process the information in order to determine the BFS and the strain along the light-guide. This process can be automatized, if a database has been formed. When a new Brillouin reflectogram appears, the MBBS profile from it must be compared with templates from the generated database. To classify the fiber types, it is necessary to evaluate the degree of matching of the explored
MBBS profile with all the database templates. To assess the degree of coincidence of the considered MBBS profiles, needs to be defined the overall part of the frequency band for analysis. The programs for the automated processing of the Brillouin reflectograms data are presented. Based on the analysis of Brillouin reflectograms, it is possible to identify a factor that had a predominant influence on the characteristics of the MBS signal in the explored sections of single-mode optical fibers. As a result of the program's work, a template is output that, according to the program's estimates according to the algorithm described above, has the best match with the downloaded image. To increase the accuracy of assessing the similarity of the explored profiles, it is also recommended to carry out calculations according to the abovedescribed algorithm when aligning not only the maximum levels, but also combine the graphs along the frequency axis. It is clear that during the overlay the frequencies of the "peaks" (BFS), there will be a very strong coincidence of the patterns, and the type of the OFs will be determined correctly, while at some temperatures a good degree of similarity with another pattern could be obtained. The obtained estimate of the BFS allows one to determine the degree of the OF strain. The identification of the MBBS profile and other characteristics of the MBS allows you to create a database various types of the OFs and different manufacturers, which can be used to classify the type of the OFs. The results presented in this exploratory development show how based on the analysis of BOTDR reflectograms, it is possible to automatically determine the type of the OF in OC, to identify a factor that has a predominant effect on the frequency response and strain in the explored sections of the OFs in FOCL, which can improve the efficiency of predicting the operational parameters of the physical channels of optical telecommunication systems.

Information about author:

Igor V. Bogachkov, Associate professor (docent) of "Communication means and information security" department of Omsk State Technical University (OmSTU), Senior Member IEEE, Omsk, Russia

Для цитирования:

Богачков И.В. Принципы автоматизации обработки данных характеристик рассеяния Мандельштама - Бриллюэна для оценки состояния оптических волокон // Т-Сomm: Телекоммуникации и транспорт. 2020. Том I4. №8. С. 47-52.

For citation:

Bogachkov I.V. (2020) Principles of automated data processing of Mandelstam - Brillouin backscatter characteristics for evaluating the state of optical fibers. T-Comm, vol. 14, no.8, Pp. 47-52. (in Russian) 
To predict the operational parameters of the physical channels of optical telecommunication systems, early diagnostics of the state of optical fibers (OFs) located in the laid optical cables (OCs) is necessary. This is indispensably for the early identification of potentially unreliable sections of the OF (sections in the OF with increased longitudinal mechanical loads, sections of fibers with significant changed temperature, etc.). Such sections over time may result to the destruction of the fiber and the disruption of the normal operation of the fiber-optic communication lines (FOCL) $[1,2]$. Therefore, in the FOCL monitoring system, it is necessary to control the physical state of the OF, since increased longitudinal mechanical loads on the OF affect its operating life) $[1,2]$.

For early diagnosis and forecasting of the state of the OFs that are in the laid OCs, Brillouin optical pulse reflectometers (BOTDR) are used, in which the back-reflected signal of the spontaneous Mandelstam - Brillouin scattering (MBS) is analyzed [1 - 4].

In the process of obtaining a trace of the distribution of the Mandelshtam - Brillouin backscatter spectrum (MBBS) along the OF, the Brillouin frequency shift (BFS) is determined (BFS $\left(f_{B}\right)$ is the position of the maximum of the MBBS). After this, a graphs of the distribution of strain along the OF is constructed $[3-7]$.

The formation of the database of the characteristics of the MBS, profiles of MBBS of the fibers of various types and manufacturers allows us to classify the fiber types in the OCs, and also to detect potentially unreliable sections of the FOCL [8-11].

Many modern types of single-mode OFs consist of several layers, the physical characteristics of which are different. In this case, the formula for $f_{B}$ should be written as

$$
f_{B}=2 v_{\text {Aeff }}\left(E_{\varepsilon}, T\right) n_{\text {eff }} / \lambda_{L},
$$

where $\lambda_{L}$ is the wavelength of the emitting laser, $v_{\text {Aeff }}\left(E_{\diamond} T\right)$ is the velocity of the hyperacoustic wave, which depends on temperature $(T)$, longitudinal strain $\left(E_{\varepsilon}\right)$ and the structure of the $\mathrm{OF}$ core, $n_{\text {eff }}$ is the effective refractive index of the medium $[1-6]$.

The interrelationship between the BFS and the changes in $E_{\diamond}$ and $T$ is determined by the formula

$$
f_{B}\left(E_{\varepsilon}, T\right)=f_{B 0}+C_{f}^{\varepsilon}\left(E_{\varepsilon}-E_{\varepsilon 0}\right)+f_{B T},
$$

where the "zero" subscripts $\left(f_{B 0}, E_{\varepsilon 0}, T_{0}\right)$ correspond to normal conditions (room temperature in the absence of longitudinal tensile forces), $C_{f}^{\varepsilon}$ and $C_{f}^{T}$ are the coupling coefficients for the corresponding parameters $\left(f_{B} \quad\left(E_{\varepsilon}\right), \quad f_{B} \quad(T) \quad\left[\begin{array}{lll}6 & - & 8\end{array}\right]\right.$, $f_{B T}=C_{f}^{T}\left(T-T_{0}\right)=C_{f}^{T} \Delta T-$ BFS offset in respect of $f_{B 0}$ due to temperature changes $[6,7]$.

In examining the characteristics of the MBS in the concrete type of the fiber, it is consideration must be given to the structure of the OFs and properties of the acoustic modes of this fiber $[6-8,11]$.

The MBBS profile (as consequence the characteristics of the MBS as a whole) come under influence by the functional dependence of the distribution of acoustic modes in the OF, their longitudinal direction. Both of them depend on the structure of the OF layers, as well as on the types and concentration of various alloying additives of the core OF [3-6]. For single-mode
OFs, when describing the MBS process, it is necessary to take into account the spatial distribution and interaction of one (main) optical and several acoustic modes.

For example, Fig. 1 shows the MBBS profile of the OF with resistant to radiation effect (CeEr008-B270418ECDF) - OF doped with erbium and cerium ions (ECDF) $[8,10]$.

The MBBS profile of the OF verities preserving the polarization state ("Panda" PS887-A270318) is shown for example in Fig. $2[8,10]$.

Figures 1 and 2 shows the start frequency of the graph in the bottom-left corner, the final frequency - in the lower right corner. The value of the BFS and the intensity of the maximum MBBS are presented in the upper right corner. The width of the MBBS (W. B. S.) and the grid spacing along the axis intensities $(5 \mathrm{~dB})$ are shown in the upper-left corner.

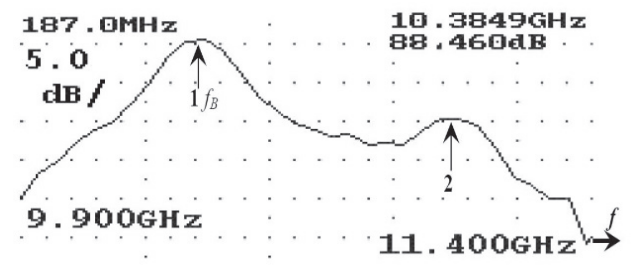

Figure 1. MBBS profile of the ECDF

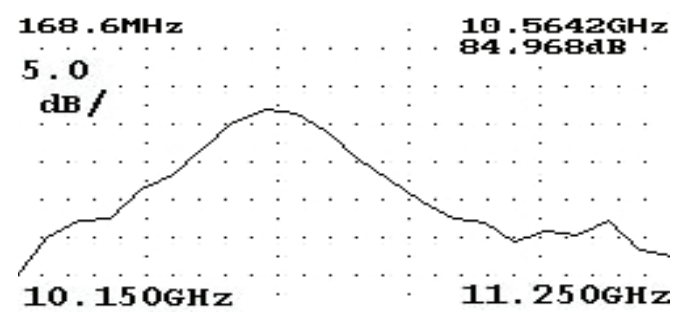

Figure 2. MBBS profile of the "Panda" fiber

The main difference between the MBBS in ECDF is as follows: in addition to the main maximum, which is observed at a frequency of $10.39 \mathrm{GHz}$, there is also an incidental "peak" at a frequency of $11.08 \mathrm{GHz}$, which just characterizes the appearance of an additional layer due to dissimilar substances.

For each type of the OF, one should fix the shape of the MBBS profile, determine own initial level $f_{B 0}$ and the characteristics of the MBS. Numerous experimental tests conducted with BOTDR and OFs of various types, manufacturers, have made it possible to create a database of MBS characteristics [6 - 14].

After uploading the data file from the BOTDR, it is necessary to process the information in order to determine the BFS and the strain along the light-guide.

An additional point is that, as noted in earlier works [1, 2, 68], one can also extract information from these data that allows one to determine the type of the OF, as well as isolate the factor that led to the change of BFS in the light-guide.

This process can be automatized, if a database has been formed [8-10].

The data necessary for the analysis of the frequency profile of the MBBS can be obtained both from the graph of the distribution of the MBBS along the light-guide, and from multireflectograms. The MBBS profile data file needed for analysis (similar to the MBBS profiles in the Fig. 1 and Fig. 2), ob- 
tained in a certain section of the fiber, has a dimension of 250x144 pixels.

Numerous experimental tests made it possible to form a database in which the corresponding MBBS profile was stored for each explored OF species [8 - 14].

When a new Brillouin reflectogram appears, the MBBS profile from it must be compared with templates (samples) from the generated database.

To classify the fiber types, it is necessary to evaluate the degree of matching of the explored MBBS profile with all the database templates.

For effective analysis, it is necessary that the original coordinate system of the loaded MBBS profile (from 0 to 250 along the abscissa and from 0 to 144 along the ordinate) be converted into real physical coordinates.

Every 18 pixels in grid of the ordinate axis correspond to the level of the back-reflected signal MBBS $(A) 5 \mathrm{~dB}$.

The formation of the real abscissa axis is much more complicated.

For an example, Fig. 3 shows the part of the data file containing the information that is necessary to obtain real coordinates along the frequency axis (abscissa).

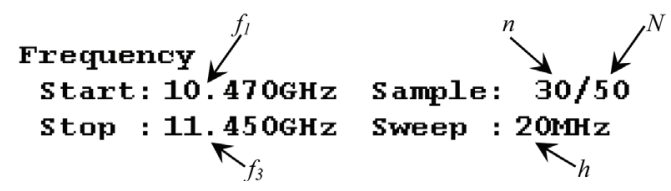

Figure 3. Characterization of the scan and abscissa grid

Frequency scanning to obtain a Brillouin reflectogram starts from the initial frequency $f_{l}\left(f_{l}=10.47 \mathrm{GHz}\right.$ in Fig. 3) at step $h$ ( $h=20 \mathrm{MHz}$ in Fig. 3). The specified final scanning frequency $f_{3}$ $\left(f_{3}=11.45 \mathrm{GHz}\right.$ in Fig. 3$)$ is achieved when all the point of division are passed $(n=N=50$ in Fig. 3$)$.

$$
f_{3}=f_{1}+h N \text {. }
$$

But the scanning process can be stopped at any step $n$ (for example, $n=30$ in Fig. 3), in which case the final frequency of the range is determined by the following formula:

$$
f_{2}=f_{1}+h(n-1) \text {. }
$$

For the scan data in Fig. 3, $f_{2}=11.05 \mathrm{GHz}$.

On the ordinate axis, the maximum value of $A\left(f_{\max }\right)$ will be observed at a frequency that is equal to the frequency of the BFS $\left(f_{\max }=f_{B}\right)$.

Figure 4 shows the MBBS profile of the explored OF (upper figure, $f_{B}=10.8765 \mathrm{GHz}$ ) and the compared sample (template) from the database (lower figure).

The grid step along the frequency axis is $h_{l}=\left(f_{2}-f_{l}\right) / 5$ along the "lines" and $h_{d}=\left(f_{2}-f_{l}\right) / 25$ along the "points". The grid spacing along the "lines" of the intensity axis is $5 \mathrm{~dB}$.

The following values were obtained for the explored MBBS profile: $f_{1}=10.55 \mathrm{GHz}, f_{2}=11.05 \mathrm{GHz}, h_{l}=100 \mathrm{MHz}, h_{d}=20 \mathrm{MHz}$.

A sample from the database corresponding to the "Corning ClearCurve LBL" OF (LBL - OF of G.652.D recommendation with improved bending characteristics [8]) is shown in the bottom figure. For it, $f_{B I}=10.8429 \mathrm{GHz}, f_{11}=10.55 \mathrm{GHz}$, $f_{2 l}=11.04 \mathrm{GHz}, h_{l l}=98 \mathrm{MHz}, h_{d l}=19.6 \mathrm{MHz}$.
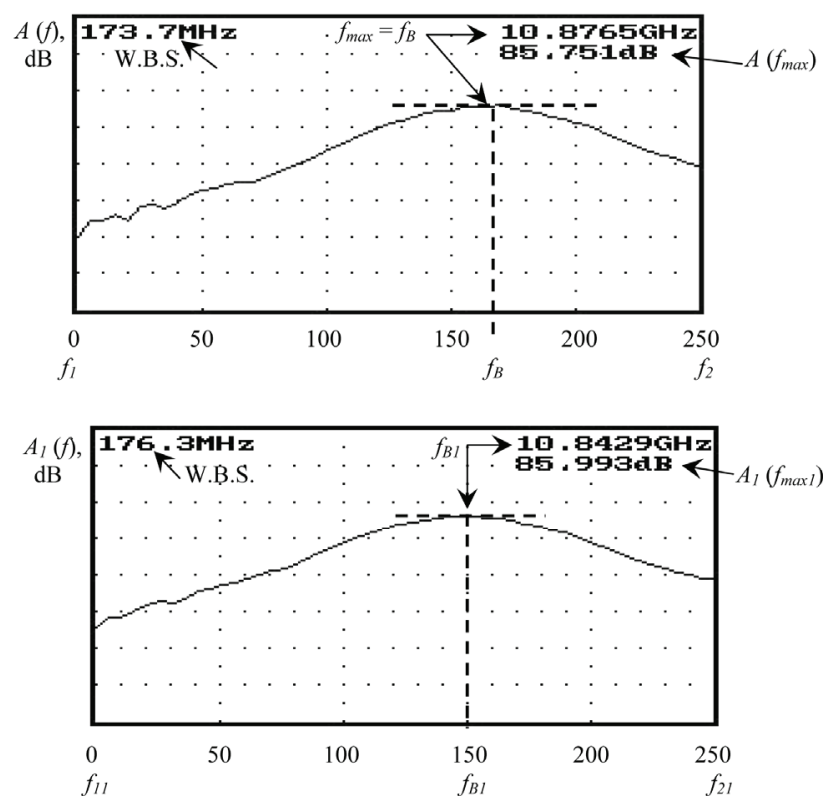

Figure 4. Scaling of the MBBS profiles of the explored OF and template

Both profiles were taken for OF under normal conditions (at room temperature and in the absence of longitudinal tensile forces).

To assess the degree of coincidence of the considered MBBS profiles, needs to be defined the overall part of the frequency range for analysis (in this example, it will be from $10.55 \mathrm{GHz}$ to $11.04 \mathrm{GHz}$ ), as well as to "align" the position of the maxima, for example, recalculate the coordinates on the abscissa axis for the template - shift all points by the value of the difference $A_{l}\left(f_{\max I}\right)$ - $A\left(f_{\max }\right)$, as a result of which the deviation of the maximum value becomes $0 \mathrm{~dB}$.

For an example, in Fig. 4, a downward shift of $0.242 \mathrm{~dB}$.

After that, a correlation assessment is carried out according to one of the known algorithms [2, 9, 10]. For example, by the r-Pearson criterion.

Taking into account the specifics of the data obtained when processing reflectograms, it is convenient to write the r-Pearson score $(R)$ in the following form:

$$
R=\frac{\sum_{i=1}^{N}\left(A_{i}-A_{A}\right)\left(A_{i}^{1}-A_{A}^{1}\right)}{\sum_{i=1}^{N} \sqrt{\left(A_{i}-A_{A}\right)^{2}} \sum_{i=1}^{N} \sqrt{\left(A_{i}^{1}-A_{A}^{1}\right)^{2}}},
$$

where $A_{A}$ - arithmetic mean of the uploaded file's ordinates, $A_{A}^{1}-A_{A}-$ arithmetic average of ordinates of the evaluated template, $N$ - number of coordinates (in our case, $N=250$ ) of the frequency band for analysis (band of the frequency matching).

The process is repeated for all database templates.

Special programs were developed for automating and accelerating the processing of Brillouin reflectograms, forming a database of characteristics of the MBS OF, evaluating the change in the frequency response and strain of the OF in Omsk State Technical University $[9,10]$.

The user may be presented with graphic images of all downloaded templates. As a result of the program's work, a template is output that, according to the program's estimates according to the algorithm described above, has the best match with the downloaded image [9] (in this case, the type of optical media is G.652). 
To increase the accuracy of assessing the similarity of the explored profiles, it is also recommended to carry out calculations according to the above-described algorithm when aligning not only the maximum levels (along the ordinate axis), but also combine the graphs along the frequency axis so that their BFS coincide $\left(f_{B 1},=f_{B}\right)$.

As an example, a shift of the template coordinates along the frequency axis to the right by $f_{B}-f_{B I}=33.6 \mathrm{MHz}$ is obtained in Fig. 4. In this case, the total part of the frequency range for analysis will be in the range from $10.59 \mathrm{GHz}$ to $11.05 \mathrm{GHz}$.

This measure will help to avoid errors in the classification of the OFs with a changed temperature or strain, since the BFS is shifted in this case, and may turn out to be more similar to the pattern of another kind of the OFs.

After "centering" the graphs both on the "Loss" axis and on the frequency axis, the similarity of data can be evaluated using a simplified algorithm:

$$
K_{r}=\sum_{i=1}^{N}\left(A_{i}-A_{i}^{1}\right)^{2} \cdot k\left(A_{i}\right) / N,
$$

where $A_{i}$ - values from the ordinate array of the researched MBBS, $A_{i}{ }_{i}$ - values from the ordinate array of the current template from the database, $k$ - the coefficient of "significance" of the reference, which in the simplest case can be taken to be equal to " 1 ".

If the data on the frequency axis ( $i$-th value in the ordinate array, $f_{i}$ ) does not match the template it will need to perform an interpolation the data under study. Given the "Lorentzian" MBBS profile in the place of maximum, second-order interpolation is optimal. Saving the results of interpolation can reduce calculations in the processing of data of the subsequent templates. The best match will be a template that has the minimum value of $K_{r}$.

Given that the significance of the samples changes as they move away from the maximum, the efficiency of the analysis can be improved by making the value of $k$ dependent on the distance in intensity from the maximum. For example, for $A_{i}$ values that differ from the maximum by $-5 \mathrm{~dB}$, you can take $k=0.95$ in (7), $k=0.9$ for $-10 \mathrm{~dB}$, and so on.

Figure 5 shows the profile of the MBBS of the G.652-fiber, which considered above, but heated to a temperature of $+60^{\circ} \mathrm{C}$.

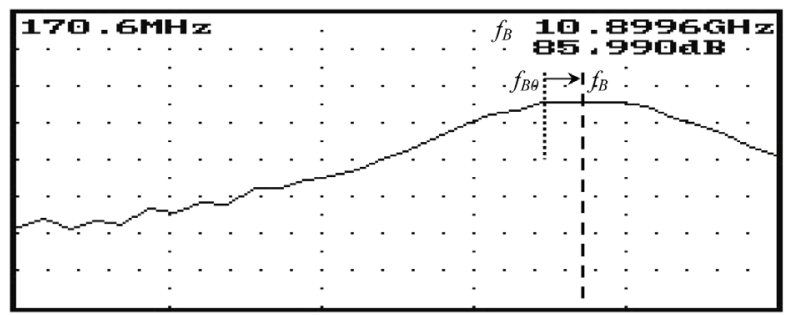

Figure 5. Characterization of the scan and abscissa grid

For the explored MBBS profile, we obtain $f_{l}=10.47 \mathrm{GHz}$, $f_{2}=11.05 \mathrm{GHz}, h_{l}=116 \mathrm{MHz}, h_{d}=23.2 \mathrm{MHz}, f_{B}=10.8996 \mathrm{GHz}$.

It is clear that during the overlay the frequencies of the "peaks" (BFS), there will be a very strong coincidence of the patterns, and the type of the OFs will be determined correctly, while at some temperatures a good degree of similarity with another pattern could be obtained.
The obtained estimate of the BFS allows one to determine the degree of the OF strain.

Figure 6 shows a screenshot of the running program [9], where after extracting the MBBS profile from the 3Dreflectogram of the BOTDR, the "Corning LEAF" OF was determined (LEAF - G.655 recommendation OF (with nonzero shifted dispersion - NZDSF) [8].

The explored OF was heated to a temperature of $+90{ }^{\circ} \mathrm{C}$.

We also observe the obtained values of the changes in the BFS $(+70.1 \mathrm{MHz})$ and the strain $(+0.13 \%)$, as well as all the characteristics of the explored MBBS profile, which the user can optionally save in the template database.

For the program to work in the mode of identifying the exposure factor and compensating for the effect of temperature on the BFS and OF strain ([7]), the "Multi" tab should be activated, after which the multi-reflection file for BOTDR must be loaded [10].

Fig. 7 shows a screenshot of the running program [10] when determining temperature changes in the OF sections. We explored the multireflectogram of the LEAF-fiber, which was heated to a temperature of $+75^{\circ} \mathrm{C}$.

The data necessary for analysis are automatically selected by the program, but in addition to the frequency profile of the fiber MBBS, there are also graphs of the strain and the level of the back-reflected signal that are displayed on the screen and are used for further analysis. The temperature ("T0"), which is taken as the initial temperature, is also displayed.

After clicking the "Calculate" button for the OF section, the file of which is loaded, the change in the BFS relative to the initial one is calculated, and then the voltage of the OF is calculated, and the temperature of the explored OF and temperature change (" $\Delta \mathrm{T}$ ") relative to the initial one are found ("T0").
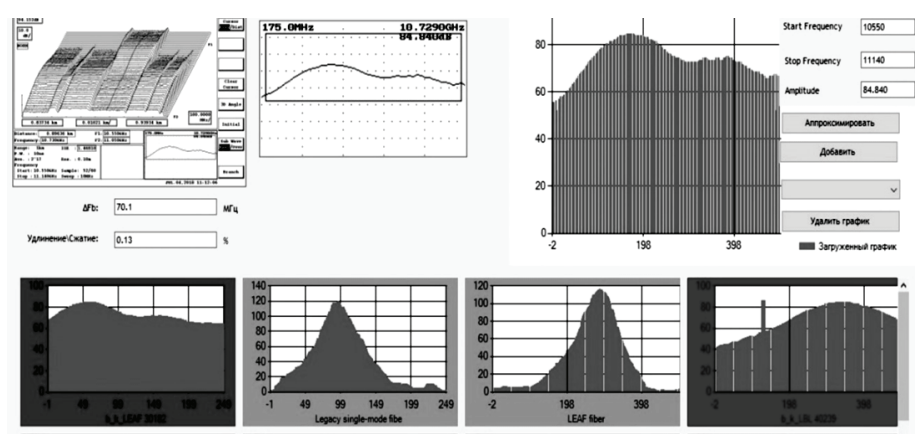

Figure 6. Screenshot of the program when determining the type of the OFs, BFS and strain degree
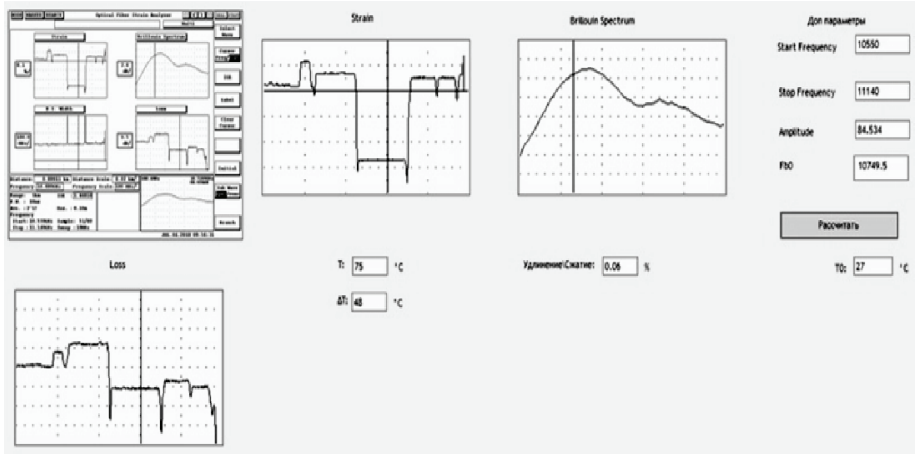

Figure 7. Screenshot of the program for determining temperature changes in the $\mathrm{OF}$ 
The temperature of the OF has changed if, in addition to changing the frequency response, there is also a change in the intensity of the back-reflected signal of the MBS.

Based on the algorithm described in [7], the change in the BFS, which is caused only by a change in temperature, is determined from the graph of the level of the back-reflected signal ("Loss"). After that, appropriate compensation is made in the dependences of the longitudinal tension $[7,10]$.

The method of Brillouin reflectometry allows early diagnosis of the state OFs in FOCL.

The results presented in this exploratory development show how based on the analysis of BOTDR reflectograms, it is possible to automatically determine the type of the OF in OC, to identify a factor that has a predominant effect on the frequency response and strain in the explored sections of the OFs in FOCL, which can improve the efficiency of predicting the operational parameters of the physical channels of optical telecommunication systems.

The identification of the MBBS profile and other characteristics of the MBS allows you to create a database various types of the OFs and different manufacturers, which can be used to classify the type of the OFs.

It is possible to automatically estimate the temperature change if in addition to the change in the BFS, there is also a change in the intensity of the backward reflected signal of the MBS. In this situation, in order to identify longitudinal tensile effects in the optical fiber, it is necessary to adjust the graphs of longitudinal strain.

\section{References}

1. Trukhina A.I., Bogachkov I.V. (2019). An investigation of the influence of the optical fiber structure on the Mandelstam - Brillouin backscatter characteristics. Systems of Signal Synchronization, Generating and Processing in Telecommunications (SINKHROINFO-2019) proceedings, Yaroslavl, 2019.

2. Bogachkov I.V., Trukhina A.I., Inivatov D.P., Kireev A.P., Gorlov N.I. (2019). A classification of optical fibers types on the spec- trum profile of the Mandelstam - Brillouin backscattering. Journal of Physics: Conference Series, vol. 1210.

3. Kobyakov A., Sauer M., Chowdhury D. (2010). Stimulated Brillouin scattering in optical fibers. Advances in Optics and Photonics Adv. Opt. Photon., vol. 2(1), pp. 1-59.

4. Ruffin A.B., Li M.-J., Chen X., Kobyakov A., Annunziata F. (2005). Brillouin gain analysis for fibers with different refractive indices. Opt. Lett., vol. 30, pp. 3123-3125.

5. Xiao H., Ren G., Dong Y., Li H., Xiao S., Wu B., Jian S. (2018). A numerical analysis of $\mathrm{GeO} 2$-doped multi-step index single-mode fiber for stimulated Brillouin scattering. Journal of Optics, vol. 20, No. 6.

6. Bogachkov I.V. (2018). Detection of initial level of Brillouin frequency shift in optical fibers of different types. Journal of Physics: Conference Series, vol. 1015, pp. 1-6.

7. Bogachkov I.V. (2020). Classification of the factors causing the change of the optical fiber strain on the basis of Brillouin reflectograms. Journal of Physics: Conference Series, vol. 1441.

8. Bogachkov I.V. (2019). Research of the features of Mandelstam Brillouin backscattering in optical fibers of various types. T-Comm, vol. 13 , No. 1 , pp. 60-65.

9. Bogachkov I.V. (2018). A program for classification of optical fiber kinds on Brillouin reflectograms. Certificate 2019610752 of state registration of computer programs. 2018662391, 07.11.2018 (Russia, OmSTU), Publ. 18.01.2019.

10. Bogachkov I.V. (2019). A program for detecting the type of impact on optical fibers and determining their strain. Certificate 2019667360 of state registration of computer programs. 2019666447, 13.12.2019 (Russia, OmSTU), Publ. 23.12.2019.

11. Bao X., Chen L. (2011). Recent Progress in Brillouin Scattering Based Fiber Sensors. Sensors, vol. 11, pp. 4152-4187.

12. Belal M., Newson T.P. (2012). Experimental examination of the variation of the spontaneous Brillouin power and frequency coefficients under the combined influence of temperature and strain. Journal of Lightwave Technology, vol. 30, No. 8, pp. 1250-1255.

13. Fang J., Sun M., Che D., Myers M., Bao F., Prohasky C., Shieh W. (2018). Complex Brillouin optical time-domain analysis. Journal of Lightwave Technology. vol. 36, No. 10, pp. 1840-1850.

14. Lanticq V., Gabet R., Auguste J.-L., Délépine-Lesoille S., Fortier S., Jaouën Y. (2007). Spontaneous Brillouin scattering modeling and measurement in various axis-symmetric optical fibers. European Conference and Exhibition on Optical Communication ECOC 2007. Berlin. 


\section{ПРИНЦИПЫ АВТОМАТИЗАЦИИ ОБРАБОТКИ ДАННЫХ ХАРАКТЕРИСТИК РАССЕЯНИЯ} МАНДЕЛЬШТАМА - БРИЛЛЮЭНА ДЛЯ ОЦЕНКИ СОСТОЯНИЯ ОПТИЧЕСКИХ ВОЛОКОН

Богачков Игорь Викторович, Омский государственный технический университет (ОмГТУ), Омск, Poccuя, bogachkov@mail.ru

\section{Аннотация}

При ранней диагностике состояния оптических волокон (ОВ), находящихся в проложенных оптических кабелях (ОК), необходимо заблаговременного выявить потенциально ненадёжные участки ОВ, которые с течением времени могут привести к разрушению ОВ и нарушению нормальной работы волоконно-оптических линий связи (ВОЛС). Для ранней диагностики ОВ используются бриллюэновские рефлектометры, в которых анализируется обратно отражённый сигнал спонтанного рассеяния Мандельштама - Бриллюэна (РМБ), и в результате определяется бриллюэновский сдвиг частоты (БСЧ), а затем строится картина распределения натяжения вдоль световода. Обсуждаются вопросы классификации разновидностей одномодовых ОВ на основе анализа характеристик РМБ. Показано, как по характеристикам спектра РМБ (СРМБ) можно определить разновидность ОВ, а также оценить изменение БСЧ и натяжения. На профиль СРМБ определённой разновидности ОВ влияет функциональная зависимость распределения акустических мод в ОВ, которая зависит от структуры слоёв ОВ. Для одномодовых ОВ при описании процесса РМБ необходимо учитывать пространственное распределение и взаимодействие основной оптической и нескольких акустических мод. После получения файла данных необходимо извлечь информацию, позволяющую определить разновидность ОВ, а также выделить фактор, который привёл к изменению БСЧ в световоде. При наличии базы данных данный процесс можно автоматизировать. При появлении новой бриллюэновской рефлектограммы профиль СРМБ из неё необходимо сравнить с шаблонами из сформированной базы данных. Для классификации разновидности ОВ необходимо оценить степень совпадения исследуемого профиля СРМБ со всеми шаблонами базы данных. Для оценки степени совпадения рассматриваемых профилей СРМБ необходимо определить общую часть диапазона частот для анализа. Представлены разработанные в ОмГТУ специальные программы для автоматизации и ускорения процесса обработки бриллюэновских рефлектограмм, формирования базы данных характеристик РМБ ОВ, оценки изменения БСЧ и натяжения ОВ. В результате работы программы выводится шаблон, который имеет наилучшее совпадение с загруженным файлом. Для повышения точности оценки подобия исследуемых профилей рекомендуется также провести вычисления не только при совмещении уровней максимумов, но и при совмещении графиков по частотной оси. Это позволит избежать ошибок при классификации ОВ с изменённой температурой или натяжением, так как БСЧ при этом сдвигается, и может оказаться более похожим на шаблон другой разновидности ОВ. Полученная оценка смещения БСЧ позволяет определить степень натяжения ОВ. Выделение профиля СРМБ и других характеристик РМБ позволяет сформировать базу данных ОВ различных типов и производителей, которую можно использовать для классификации типа ОВ. Представленные в данном исследовании результаты показывают, как на основании анализа рефлектограмм можно автоматически определять разновидность ОВ в ОК, выявлять фактор, оказывающий влияние на БСЧ и натяжение в исследуемых участках ОВ, что позволяет повысить эффективность ранней диагностики состояния ОВ.

Ключевые слова: одномодовое оптическое волокно, рассеяние Мандельштама - Бриллюэна, отражённый сигнал, бриллюэновский сдвиг частоты, натяжение, профиль спектра рассеяния.

\section{Литература}

І. Трухина А.И., Богачков И.В. Исследования влияния структуры оптических волокон на характеристики рассеяния Мандельштама - Бриллюэна // Системы синхронизации, формирования и обработки сигналов. 2019. Т. І0, № 3. С. I5-І9.

2. Богачков И.В., Трухина А.И., Иниватов Д.П., Киреев А.П., Горлов Н.И. Классификация оптических волокон по профилю спектра рассеяния Мандельштама - Бриллюэна // Динамика систем, механизмов и машин. 2018. Т. 6, № 4. С. 96-100.

3. Kobyakov A., Sauer M., Chowdhury D. Stimulated Brillouin scattering in optical fibers // Advances in Optics and Photonics. 2010. Vol. 2 (I). P. I-59.

4. Ruffin A. B., Li M.-J., Chen X., Kobyakov A., Annunziata F. Brillouin gain analysis for fibers with different refractive indices // Opt. Lett. 2005. Vol. 30.

P. $3123-3 \mid 25$.

5. Xiao H., Ren G., Dong Y., Li H., Xiao S., Wu B., Jian S. A numerical analysis of GeO2-doped multi-step index single-mode fiber for stimulated Brillouin scattering // Journal of Optics. 2018. Vol. 20. № 6.

6. Bogachkov I.V. Detection of initial level of Brillouin frequency shift in optical fibres of different types // Journal of Physics: Conference Series, 2018. Vol. 1015 (20I8). P. I-6.

7. Богачков И.В. Классификация факторов, вызывающих изменение натяжения оптических волокон, на основании бриллюэновских рефлектограмм // Динамика систем, механизмов и машин. 2019. Т. 7. № 4. С. I84-19I.

8. Богачков И.В. Изучение особенностей рассеяния Мандельштама - Бриллюэна в оптических волокнах различных видов // Т-Сотт: Телекоммуникации и транспорт. 2019. Т. 13, № І. С. 60-65.

9. Свидетельство о государственной регистрации программы для ЭВМ 2019610752. Программа для классификации разновидностей оптических волокон по бриллюэновским рефлектограммам / И. В. Богачков; заявитель ОмГТУ. заявл. 07.II.20I8. № 201866239I; опубл. I8.0I.2019.

10. Свидетельство о государственной регистрации программы для ЭВМ №2019667360. Программа для выявления типа воздействия на оптические волокна и определения их натяжения / И. В. Богачков; заявитель ОмГТУ. заявлено І 3.12.2019. 2019666447/69; опубл. 23.12.2019.

II. Bao X., Chen L. Recent Progress in Brillouin Scattering Based Fiber Sensors // Sensors, 20II. Vol. II. P. 4I52-4I87.

12. Belal M., Newson T.P. Experimental examination of the variation of the spontaneous Brillouin power and frequency coefficients under the combined influence of temperature and strain // Journal of Lightwave Technology, 20I2. Vol. 30. No. 8. P. I250-I255.

13. Fang J., Sun M., Che D., Myers M., Bao F., Prohasky C., Shieh W. Complex Brillouin optical time-domain analysis // Journal of Lightwave Technology. 2018. Vol. 36. No. 10. P. I840-1850.

14. Lanticq V., Gabet R., Auguste J.-L., Delepine-Lesoille S., Fortier S., Jaou?n Y. Spontaneous Brillouin scattering modeling and measurement in various axissymmetric optical fibers // European Conference and Exhibition on Optical Communication ECOC 2007. Berlin, 2007.

\section{Информация об авторе:}

Богачков Игорь Викторович, к.т.н., доцент; доцент кафедры "Средства связи и информационная безопасность" Омского государственного технического университета (ОмГТУ), Senior Member IEEE, Омск, Россия 